УДК 347.6

DOI https://doi.org/10.32849/2663-5313/2021.1.07

\title{
Віталій Чернега,
}

канд. юрид. наук, дочент,

доцент кафедри підприємницького та корпоративного права

Київського начіонального економічного університету імені Вадима Гетьмана

\section{СПЕЦІАЛІЗОВАНІ НОРМИ СІМЕЙНОГО ПРАВА}

Статтю присвячено спеціалізованим нормам сімейного права. Підтримано підхід, відповідно до якого такі своєрідні правила посідають нішу в системі норм сімейного права, які найкраще позначати як спечіалізовані. Розглянуто прагнення українських і зарубіжних представників юридичної науки трактувати сутність спеиіалізованих норм права. Поняття спеиіалізованих норм сімейного права сформульовано як утілені в сімейному законодавстві своєрідні правила (норми-цілі сімейного права, норми-принципи сімейного права, норми-дефініції сімейного права, норми-строки сімейного права, оперативні та колізійні норми сімейного права), що мають двоелементну структуру (гіпотезу й диспозицію) $і$ не встановлюють конкретних правових моделей поведінки учасників сімейних відносин, функиіональний потениіал яких у механізмі правового регулювання сімейних відносин надає визначально-забезпечувальний ефект і залежить від певного виду таких норм сімейного права. Визначено такі ознаки спеціалізованих норм сімейного права: по-перше, вони являють собою втілені в сімейному законодавстві своєрідні правила, що мають розгалужену систему; по-друге, до їх структури належать лише гіпотеза та диспозичія; по-третє, вони не встановлюють правила поведінки учасників сімейних правовідносин; по-четверте, кожний вид спечіалізованих норм сімейного права має власний функціональний потенціал у механізмі правового регулювання сімейних відносин, спрямований на визначально-забезпечувальний ефект. 3'ясовано, шо такі норми сімейного права мають двоелементну структуру (гіпотезу й диспозииію). Задля формування иілісного наукового уявлення про види аналізованих норм права побіжно здійснено дайджест системи спеиіалізованих норм права й системи спечіалізованих норм иивільного права. Автором сформовано систему спеиіалізованих норм сімейного права, до якої зараховано, по-перше, норми-иілі сімейного права; по-друге, норми-приниипи сімейно20 права; по-третє, норми-дефініиії сімейного права; по-четверте, норми-строки сімейного права; по-n'яте, оперативні норми сімейного права; по-шосте, колізійні норми сімейного права. Зосереджено науковий інтерес на нормах-строках сімейного права. На прикладних ілюстраціях розглянуто оперативні та колізійні норми сімейного права.

Ключові слова: спеціалізовані норми сімейного права, норми-цілі сімейного права, нормипринципи сімейного права, норми-дефініції сімейного права, норми-строки сімейного права, оперативні норми сімейного права, колізійні норми сімейного права, норми сімейного права, механізм правового регулювання сімейних відносин.

Постановка проблеми. Нині $є$ низка передумов до системного осмислення спеціалізованих норм сімейного права, які відрізняються від регулятивних та охоронних норм сімейного права за власним функціональним призначенням у механізмі правового регулювання сімейних відносин. Коло проблем, що потребують пильної уваги наукової громадськості, висвітлюватиметься в дослідженні.

Спеціалізовані норми права в механізмі правового регулювання є об'єктом уваги представників як загальної теорії права, так i різногалузевих юридичних наук. У новітніх наукових публікаціях розкрито сутність норм-цілей сімейного права та їх значення в механізмі правового регулювання сімейних відносин [15, с. 133-136]; визначено поняття, систему і структуру норм-дефініцій сімейного права [16, с. 149-152]; удосконалено норму-дефініцію «сім'я» [17, с. 143-146].
Проте ні в навчальній літературі, ні в науковій думці спеціалізовані норми сімейного права досі комплексно не розглядалися.

\footnotetext{
Метою статті $є$ визначення поняття, ознак, структури, системи спеціалізованих норм сімейного права, їх місця в системі норм сімейного права, а також розкриття значення в механізмі правового регулювання сімейних відносин.
}

Виклад основного матеріалу. У юридичній літературі не сформовано єдиного найменування спеціалізованих норм права. Їх розглядають як нетипові нормативні приписи [3, с. 113-118; 11, с. 24]; аномалії в праві [8, с. 130]; нормативно-правові приписи, що не виражають норм права [4, с. 13]; вихідні норми права $[9$, с. 230]; нормативні узагальнення високого ступеня абстрактності [18, с. 159-160]; спеціалізовані (нетипові) 
норми права [13, с. 281-282]; спеціалізовані норми права [1, с. 70-72; 2, с. 22-30; 6 , с. $1-260 ; 10$, с. 159]. Найприйнятнішою видається остання з варіацій.

Оскільки в науці сімейного права відсутні прагнення трактування поняття спеціалізованих норм права, доцільно звернутися хоча б до кількох набутків у царині загальної теорії українського та зарубіжного права, а також наявних досягнень спорідненої доктрини цивільного права. Так, О.Ф. Скакун окреслює їх як «нетипові розпорядження, у яких відсутні ті чи інші властивості, ознаки, об'єктивно притаманні класичній моделі норми права» [13, с. 281].

За визначенням Ю.В. Кривицького, спеціалізованими нормами права $€$ «обов'язкові формально визначені, цілісні, логічно завершені правила підвищеного рівня загальності, що відповідають визнаній у суспільстві мірі свободи, рівності та справедливості, установлені чи санкціоновані та гарантовані державою або іншим уповноваженим суб'єктом правотворчості з метою субсидіарного впорядкування суспільних відносин і забезпечення єдності (інтегративності) та одноманітності (уніфікованості) дії механізму правового регулювання» [6, с. 103].

А.В. Баранов спеціалізовану норму права трактує як «особливо сформульоване загальнообов'язкове, формально визначене правило загального характеру, яке виконує в механізмі правового регулювання специфічні функції, що виражаються в тому, що ці норми мають визначально-забезпечувальний вплив на систему праву» [2, с. 29].

За визначенням О.А. Кузнєцової, цивільно-правові спеціалізовані норми являють собою «норми-приписи, що мають двочленну структуру (гіпотезу та диспозицію), не містить конкретні моделі поведінку й виконують специфічні функції в системі цивільного права» [7, с. 5-6].

Зважаючи на викладене вище, а також з огляду на своєрідність сімейно-правової сфери, поняття спеціалізованих норм сімейного права резонно визначити як утілені в сімейному законодавстві своєрідні правила (норми-цілі сімейного права, норми-принципи сімейного права, норми-дефініції сімейного права, норми-строки сімейного права, оперативні та колізійні норми сімейного права), що мають двоелементну структуру (гіпотезу та диспозицію) і не встановлюють конкретних правових моделей поведінки учасників сімейних відносин, а функціональний потенціал яких у механізмі правового регулювання сімейних відносин надає визначально-забезпечувальний ефект і залежить від певного виду таких норм сімейного права.
Зважаючи на те що в літературі раніше не зверталася увага на ознаки спеціалізованих норм сімейного права, доцільно представити науковій громадськості власне бачення. Тому до «каталогу» ознак таких норм сімейного права варто зарахувати: а) вони являють собою втілені в сімейному законодавстві своєрідні правила, що мають розгалужену систему; б) до їх структури належать лише гіпотеза та диспозиція; в) вони не встановлюють правила поведінки учасників сімейних правовідносин; г) кожний вид спеціалізованих норм сімейного права має власний функціональний потенціал у механізмі правового регулювання сімейних відносин, спрямований на визначально-забезпечувальний ефект.

У навчальних і наукових виданнях через відсутність комплексного вивчення спеціалізованих норм сімейного права донині не порушувалося питання про їх систему, тоді як, наприклад, теоретики права не можуть дійти згоди в питанні про систему (види) спеціалізованих норм права. Так, розглядаючи «номенклатуру» спеціалізованих норм права, автори до неї зараховують дефінітивні норми; норми-принципи; оперативні норми; колізійні норми; норми-строки (темпоральні норми); норми-презумпції; нормипреюдиції; норми-фікції; норми-конструкції. Окремо виокремлено прогностичні та декларативні норми. Водночас наголошується, що як спеціалізовані норми права недоцільно вважати установчі норми та норми-засади [14, c. $180-181]$.

Інший перелік міститься в одному 3 підручників із теорії права, згідно з яким до спеціалізованих норм права зараховано: норми-завдання; норми-принципи; нормипринципи; колізійні норми; оперативні норми; норми-дефініції; норми-строки; норми-презумпції; норми-преюдиції; нормифікції [5, с. 240-242].

Вужчий каталог «похідних (що забезпечують)» норм права пропонує О.Ф. Скакун, зараховуючи до них загальнозакріпні норми (норми-начала); установчі норми (норми-принципи); прогностичні норми (норми-цілі); декларативні норми (нормиоголошення); дефінітивні норми (нормидефініції); оперативні норми (нормиінструменти); колізійні (норми-арбітри) [13, с. 282-284].

Дослідник спеціалізованих норм права в механізмі правового регулювання Ю.В.Кривицький до них зараховує норми-дефініції; норми-принципи; норми-декларації. Водночас згаданий автор заперечує належність норм-презумпцій, норм-преюдицій, нормстроків, оперативних і колізійних норм, юри- 
дичних конструкцій до спеціалізованих норм права [6, с. 111-136]

У зарубіжній загальнотеоретичній юриспруденції деякі автори прагнуть представити систему спеціалізованих норм права Наприклад, А.В. Баранов до них зараховуе системовизначальні норми права (установчі норми права, норми-цілі права та нормизавдання права, норми-принципи права, дефінітивні норми права); системоспрощувальні норми права (норми-фікції права та норми-презумпції права); системозабезпечувальні норми права (колізійні й оперативні норми права) [2, с. 27-29].

У спорідненій галузевій юридичній науці теж є прагнення з'ясувати систему спеціалізованих норм. Наприклад, представник цивільно-правової науки та судової практики Я.М. Романюк, розглядаючи спеціалізовані норми, до них зараховує, по-перше, відправні цивільноправові норми (норми-засади цивільного права, норми-принципи цивільного права, визначально-установчі норми цивільного права, норми-дефініції цивільного права); по-друге, системоспрощувальні норми цивільного права; по-третє, системозберігаючі норми цивільного права [12, с. 15].

Отже, до системи спеціалізованих норм сімейного права варто зарахувати: а) нормицілі сімейного права; б) норми-принципи сімейного права; в) норми-дефініції сімейного права; г) норми-строки сімейного права; г) оперативні норми сімейного права; д) колізійні норми сімейного права.

Доцільно зупинитися на спеціалізованих нормах сімейного права, увага до яких до яких не була пильно прикута з боку наукової спільноти. Норми-строки сімейного права це правила обчислення строків у сімейно-правовій сфері. Строки, установлені у Сімейному кодексі України (далі - СКУ), обчислюються згідно із Цивільним кодексом України (далі - ЦКУ) (ч. 1 ст. 12 СКУ). У механізмі правового регулювання сімейних відносин важливо з'ясувати початок перебігу строку (ч. 1 ст. 253 ЦКУ), його закінчення (ст. 254 ЦКУ), а також порядок учинення дій в останній день строку (ч. 1 ст. 255 ЦКУ).

У СКУ закріплено також оперативні норми сімейного права. Ідеться про «норми про норми», які зазвичай розуміють як «норми, роль яких виражається в установленні дати вступу (зміни, припинення) нормативно-правового акта в силу, в його поширенні на нове коло суспільних відносин, на новий строк» [13, с. 283].

Прикладними ілюстраціями оперативних норм сімейного права $€$ положення розділу 7 СКУ «Прикінцеві положення».
Насамперед $є$ підстави констатувати, що в п. 1 Прикінцевих положень СКУ в редакції Закону від 10 січня 2002 р. передбачалося, що Кодекс набирає чинності 31 січня 2003 р. Проте затримка з ухваленням нового ЦКУ, з окремими положеннями якого тісно пов'язаний масив норм СКУ, стала причиною зміни терміну набрання чинності останнім. Законом України «Про внесення змін до Сімейного кодексу України» від 26 грудня 2002 р. встановлено, що Кодекс набирає чинності водночас із набранням чинності ЦКУ. Отже, СКУ набрав чинності водночас із ЦКУ 1 січня 2004 р.

Як приклади доцільно також розглядати положення п. 2 Прикінцевих положень СКУ. Зі вступом у дію СКУ втратив чинність Кодекс про шлюб і сім'ю України, крім розділу 5 «Акти цивільного стану», який зберігав чинність у частині, що не суперечила СКУ, до ухвалення спеціального закону (абз. 1 п. 2 Прикінцевих положень СКУ), тобто до ухваленого парламентом Закону України «Про державну реєстрацію актів цивільного стану» від 1 липня 2010 р.

Разом із Кодексом про шлюб і сім'ю України визнані такими, що втрачають чинність зі вступом у дію СКУ, Закон Української РСР «Про затвердження Кодексу про шлюб і сім'ю Української РСР» від 20 червня 1969 р. (абз. 2 п. 2 Прикінцевих положень СКУ) та Указ Президії Верховної Ради України Української РСР «Про порядок введення в дію Кодексу про шлюб і сім'ю Української РСР» від 29 грудня 1969 р. (абз. 3 п. 2 Прикінцевих положень СКУ).

Ще однією з прикладних ілюстрацій оперативних норм сімейного права є положення пункту 2-1 Прикінцевих положень СКУ, відповідно до якого під час карантину, установленого Кабінетом Міністрів України задля запобігання поширенню коронавірусної хвороби, строки, визначені статтями $72,128,129$, 139 СКУ, продовжуються на строк дії такого карантину. Його доповнено згідно із Законом України «Про внесення змін до деяких законодавчих актів України, спрямованих на забезпечення додаткових соціальних та економічних гарантій у зв'язку з поширенням короно вірусної хвороби (COVID-19)» від 30 березня $2020 \mathrm{p}$.

Резонно також розглянути колізійні норми сімейного права. Для розуміння їх сутності логічно навести класичне загальнотеоретичне трактування колізійних норми права, якими є норми, які за наявності суперечностей між окремими нормативними актами 3 того самого предмета регулювання мають застосовуватися в певному випадку, тобто це «норми, що регулюють вибір 
норми» [13, с. 284]. Яскравим прикладом колізійної норми сімейного права $є$ положення ч. 2 ст. 13 СКУ: якщо в міжнародному договорі України, укладеному в установленому порядку, містяться інші правила, ніж ті, що встановлені відповідним актом сімейного законодавства, застосовуються правила відповідного міжнародного договору України. До міжнародних договорів, які є частиною національного законодавства України, належать: а) Конвенція про захист прав людини і основоположних свобод від 4 листопада 1950 р. (набрала чинності для України 11 травня 1997 р.), ст. 8 якої гарантує право на повагу до приватного й сімейного життя. Таке положення відтворено в ст. 32 Конституції нашої держави та в ч. 4 ст. 7 СКУ. У статті 12 згаданої Конвенції йдеться про те, що чоловік і жінка, які досягли шлюбного віку, мають право на шлюб і створення сім'ї згідно з національним законодавством, що регулює здійснення такого права; б) Конвенція про ліквідацію всіх форм дискримінації щодо жінок (прийнята Генеральною Асамблеєю ООН 18 грудня 1979 р., а набрала чинності для України 24 грудня 1980 р.); в) Конвенція про права дитини від 20 листопада 1989 р. (набрала чинності для України 27 вересня 1991 р.). Ї̈̈ положення віддзеркалено в статтях 51, 52 Конституції нашої держави, а також у ч. 7 ст. 7, низці інших статей СКУ; г) Конвенція країн-учасниць СНД «Про правову допомогу і правові відносини з цивільних, сімейних і кримінальних справ» від 22 січня 1993 р. (набрала чинності для України 14 квітня 1995 р.). Згадана Конвенція застосовується у відносинах України 3 Азербайджанською Республікою, Грузією, Киргизькою Республікою, Республікою Білорусь, Республікою Вірменія, Республікою Молдова, Республікою Таджикистан, Республікою Узбекистан, Російською Федерацією, Туркменістаном; г) Європейська конвенція про здійснення прав дітей від 25 січня 1996 р. (набрала чинності для України 1 квітня 2007 р.); д) Конвенція про стягнення аліментів за кордоном від 20 червня 1956 р. (набрала чинність для України 19 жовтня 2006 р.); е) Конвенція про контакт 3 дітьми від 15 травня 2003 р. (набрала чинності для України 1 січня 2007 р.); є) Європейська конвенція про правовий статус дітей, народжених поза шлюбом, від 15 жовтня 1975 р. (набрала чинності для України 27 червня 2009 р.); ж) Європейська Конвенція про визнання та виконання рішень стосовно опіки над дітьми та про поновлення опіки над дітьми від 28 травня 1980 р. (набрала чинності для України 1 листопада 2008 p.).

\section{Висновки}

Отже, спеціалізованими нормами сімейного права $€$ втілені в сімейному законодавстві своєрідні правила (норми-цілі сімейного права, норми-принципи сімейного права, норми-дефініції сімейного права, нормистроки сімейного права, операційні та колізійні норми сімейного права), що мають двоелементну структуру (гіпотезу й диспозицію) i не встановлюють конкретних правових моделей поведінки учасників сімейних відносин, функціональний потенціал яких у механізмі правового регулювання сімейних відносин надає визначально-забезпечувальний ефект і залежить від певного виду таких норм сімейного права. До ознак таких норм сімейного права варто зарахувати: а) вони являють собою втілені в сімейному законодавстві своєрідні правила, що мають розгалужену систему; б) до їх структури належать лише гіпотеза та диспозиція; в) вони не встановлюють правила поведінки учасників сімейних правовідносин; г) кожний вид спеціалізованих норм сімейного права має власний функціональний потенціал у механізмі правового регулювання сімейних відносин, спрямований на визначально-забезпечувальний ефект.

\section{Список використаних джерел:}

1. Алексеев С.С. Общая теория права : в 2 т. Москва : Юрид. лит., 1982. Т. 2. 300 с.

2. Баранов А.В. К вопросу о понятии и месте специализированных норм в системе российского права. Вестник Омского университета. Серия «Право». 2017. № 1 (50). С. 22-30.

3. Горшенев B.M. Нетипичные нормативные предписания в праве. Советское государство и право. 1978. № 3. С. 113-118.

4. Давыдова М.Л. Нормативно-правовые предписания в российском законодательстве : учебное пособие. Волгоград : Изд-во Волгогр. ун-та, 2001. $92 \mathrm{c}$.

5. Загальна теорія держави і права : підручник для студентів юридичних вищих навчальних закладів / М.В. Цвік, О.В. Петришин, Л.В. Авраменко та ін. ; за ред. докт. юрид. наук, проф., акад. АПрН України М.В. Цвіка, докт. юрид. наук, проф., акад. АПрН України О.В. Петришина. Харків : Право, 2009. 584 с

6. Кривицький Ю.В. Спеціалізовані норми права в механізмі правового регулювання : дис. ... канд. юрид. наук : 12.00.01. Київ, 2010. 260 с.

7. Кузнецова О.А. Специализированные нормы российского гражданского права: теоретические проблемы : автореф. дисс. ... докт. юрид. наук : 12.00 .03 . Екатеринбург, 2007. 43 c.

8. Мирошниченко Т.Н. Диалектика соотношения типичного, нетипичного и нетрадиционного в праве. Проблемы сочиалистической законности : республик. межвуз. сб. Харьков, 1985. Вып. 5. С. 128-132. 
9. Морозова Л.А. Теория государства и права : учебник. 5-е изд., перераб. и доп. Москва : Норма : ИНФА-М, 2014. 464 c.

10. Нормы советского права: проблемы теории / под ред. В.К. Бабаева, М.И. Байтина. Саратов : Изд-во Саратовского ун-та, 1987. 248 с.

11. Рыбаков А.В. Нетипичные нормы права. Вестник Омского университета. Серия «Право». 2013. № 3. C. 24-29.

12. Романюк Я.М. Проблеми застосування цивільно-правових норм у цивільному судочинстві України : дис. ... докт. юрид. наук : 12.00 .03$. Київ, 2017. 518 с.

13. Скакун О.Ф. Теорія держави і права : підручник / пер. $з$ рос. С.О. Бураковського. Харків Консум, 2006. 656 c.

14. Теорія держави і права : підручник / кол. авт. ; кер. авт. кол. канд. юрид. наук, проф. Ю.А. Ведєрніков. 3-є вид., перероб. і доп. Дніпро : Дніпроп. держ. ун-т внутр. справ, 2016. $480 \mathrm{c.}$
15. Чернега В.М. Норми-цілі сімейного права в механізмі правового регулювання сімейних відносин. Проблеми вдосконалення приватноправових механізмів набуття, передачі, здійснення та захисту суб'єктивних иивільних та сімейних прав : матер. Наук.-практ. конф., присвяченої пам'яті проф. Ч.Н. Азімова та 20-річчю 3 дня створення кафедри цивільного права № 2 (м. Харків, 29 листопада 2019 р.). Харків : Право, 2019. C. $133-136$

16. Чернега В.М. Поняття, система та структура норм-дефініцій сімейного права. Порівняльно-аналітичне право. 2019. №4. С. 149-152.

17. Чернега В.М. Удосконалення нормидефініції «сім'я». Юридичний науковий електронний журнал. 2019. № 6. С. 143-146. URL: http:// www.lsej.org.ua/6_2019/34.pdf (дата звернення: 20.12.2020)

18. Шафиров В. М. Естественно-позитивное право: Введение в теорию : монография. Красноярск : ИЦ КрасГУ, 2004. 260 с.

Vitalii Cherneha. Specialized norms of family law

The article is devoted to specialized norms of family law. The approach according to which such peculiar rules occupy a niche in the system of rules of family law, which are best marked as specialized, is supported. The desire of Ukrainian and foreign representatives of legal science to interpret the essence of specialized legal norms is considered. The concept of specialized norms of family law is formulated as embodied in family legislation peculiar rules (norm-purposes of family law, norm-principles of family law, norm-definitions of family law, norm-terms of family law, operational and contentious norms of family law), which have a two-element structure (hypothesis and disposition) and not establish specific legal models of behavior of participants in family relations, and the functional potential of which in the mechanism of legal regulation of family relations has a determining and supporting effect and depends on a certain type of such rules of family law. Signs of specialized norms of family law are determined. It was found that such rules of family law have a two-element structure (hypothesis and disposition). In order to form a holistic scientific idea of the types of analyzed norms of law, a digest of the system of specialized norms of law and the system of specialized norms of civil law was briefly implemented. The author has formed a system of specialized norms of family law, which includes: first, the norm-purposes of family law; secondly, norm-principles of family law; thirdly, norm-definitions of family law; fourth, the norm-terms of family law; fifth, the operational norms of family law; sixth, contentious norms of family law. The scientific interest is focused on the norm-terms of family law. The applied illustrations consider operational and contentious norms of family law.

Key words: specialized norms of family law, norm-purposes of family law, norm-principles of family law, norm-definitions of family law, norm-terms of family law, operational norms of family law, contentious norms of family law, rules of family law, mechanism of legal regulation of family relations. 